\title{
DEVELOPMENT OF NANOPARTICULATE DRUG DELIVERY SYSTEM FROM MARINE SOURCE AGAINST HUMAN IMMUNODEFICIENCY VIRUS
}

\author{
HARIKRISHNAN N ${ }^{1}$, ANAS S MOHAMIED ${ }^{2}$, GEJALAKSHMI ${ }^{1 *}$
}

${ }^{1}$ Faculty of Pharmacy, Dr. M. G. R. Educational and Research Institute, Chennai, Tamil Nadu, India. ${ }^{2}$ Faculty of Pharmacy, Omar Al Mukthar University, Al-Bayda, Libya. Email: gejampharm@gmail.com

Received: 16 September 2019, Revised and Accepted: 04 November 2019

\section{ABSTRACT}

Objective: Nanotechnology techniques are a creation and exploitation of materials, devices, and systems through the control of matter on the nanometer length scale, i.e., involvement of atoms, molecules, and supramolecular structures. Every existing treatment modalities against human immunodeficiency virus (HIV) offer a marginal increase in the life expectancy as chitosan was converted to its derivative aminoethyl chitosan by chemical method evaluated for anti-HIV activity.

Methods: Isolation of chitosan from crab shell by chemical method involves four basic steps; protein separation, calcium carbonate separation, deproteinization, and demineralization.

Results: The results revealed the anti-HIV activity of the prepared nanoparticulate system. Cytotoxicity assay of the nanoparticulate system was carried out and the cytotoxic concentration 50\% (CC50) value was found to be $38.07 \pm 1.42 \mu \mathrm{g} / \mathrm{ml}$, indicating that the nanoparticulate system is not cytotoxic. HIV-1 infection inhibition assay was carried out and the nanoparticulate system showed excellent inhibitory activity with a half-maximal inhibitory concentration $\left(\mathrm{IC}_{50}\right.$ ) value of $3.75 \pm 0.57 \mu \mathrm{g} / \mathrm{ml}$.

Conclusions: It concludes, the CC50 and inhibitory concentration $50 \% \mathrm{IC}_{50}$ values, the selectivity index of the nanoparticle was found to be 17.65 compared to the standard drug nevirapine (82.32), indicating the usefulness of the formulated nanoparticulate system as potential anti-HIV agent.

Keywords: Drug delivery, Nanoparticle, Marinesource.

(C) 2020 The Authors. Published by Innovare Academic Sciences Pvt Ltd. This is an open access article under the CC BY license (http://creativecommons. org/licenses/by/4. 0/) DOI: http://dx.doi.org/10.22159/ajpcr.2020.v13i1.35725

\section{INTRODUCTION}

Human immunodeficiency virus (HIV) infection is the causative agent for acquired immunodeficiency syndrome (AIDS); it is a public health problem. Anti-HIV therapy involving chemical drugs has expanded the life quality of HIV/AIDS patients. Citing example for nanoparticles can be used to change drug solubility and bioavailability or to allow multiple drugs to be combined into the similar delivery vehicle. Nanoparticles can also be targeted to particular cell or tissue types, explaining accuracy that may not normally be a characteristic of the incorporated drug [1]. There is an urgent requirement of medicinal agents capable of specifically inhibiting HIV due to its globally extensive infection. Most of the clinically useful anti-HIV agentsarenucleosides, but their use is restricted due to their severe toxicity and emerging drug resistance. Natural products, has structural diversity is so broad, which are good sources for the effective finding of anti HIV agents with reduced toxicity. Nanotechnology is a potent multidisciplinary field that has the impact to advance the treatment and prevention of HIV/AIDS completely. The therapeutic benefits of using nanomedicine over conventional HIV therapies include the capacity to insert, encapsulate, or conjugate a variety of drugs into required target-specific cell populations and to attain tunable and site-specific drug release [2]. METHODS

Collection of marine products: Crab shell

Crab shells were collected from a local fish market, Cheruthuruthy, and it was then washed, dried, and powdered.

\section{Isolation of chitosan from crab shell [5-8]}

Isolation of chitosan from crab shell by chemical method involves two basic steps; protein separation, calcium carbonate separation, deproteinization, and demineralization.

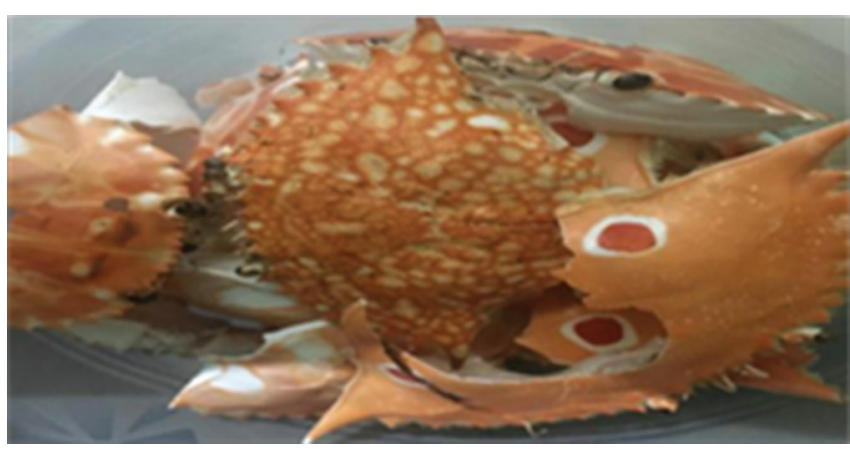

Determination of physicochemical characterization of chitosan powder $[9,10]$

Moisture

Moisture content of chitosan containing sample tubes was determined using the gravimetric method reported by Black et al. Briefly, the samples were dried to constant weight in oven at $105^{\circ} \mathrm{C}$ and moisture content was calculated as follows:

$$
\text { Moisture }(\%)=\frac{W_{1}-W_{2}}{W} \times 100
$$

Where,

$\mathrm{W}_{1}=$ Weight $(\mathrm{g})$ of sample before drying

$\mathrm{W}_{2}=$ Weight $(\mathrm{g})$ of sample after drying.

Ash

The ash content with crucible having lid was weighed when sample containing tubes turns to gray. The percentage of ash was calculated as follows: 


$$
\operatorname{Ash}(\%)=\frac{\text { Weigh } \text { to fash }(\mathrm{g})}{\text { Weight of sample(g) }}
$$

\section{Viscosity}

Viscosity of the chitosan was determined with a Brookfield viscometer (Model DV-IIp Brookfield) as described by Fernandez, with few modifications. Chitosan solution was prepared using $1 \%$ acetic acid at $1 \%$ concentration on a dry weight basis. Measurement was made in triplicates using spindle number 2 at $50 \mathrm{rpm}$ at $28^{\circ} \mathrm{C}$ for each solution and the values were reported in centipoises (cps) units.

Viscosity-average molecular weight (Mv)

The molecular weight in Dalton for all chitosan samples was measured by dissolving $1 \%$ chitosan $(\mathrm{w} / \mathrm{v}$ ) each in $1 \%$ glacial acetic acid. Intrinsic viscosity ( $\eta$ ) was measured using Ubbelohde glass capillary viscometer and molecular weight of chitosan was determined using Mark-Houwink equation relating intrinsic viscosity with empirical viscometric constants; $\mathrm{K}=1.81 \times 103 \mathrm{~cm}^{3} / \mathrm{g}$ and $\mathrm{a}=0.93$ for chitosan as follows: $\mathrm{y}=\mathrm{KMa}$

\section{Solubility}

Solubility of prepared chitosan in both water and acetic acid was determined.

\section{Degree of deacetylation}

Weight accurately $0.25 \mathrm{~g}$ of chitosan $+20 \mathrm{ml}$ of $0.1 \mathrm{M} \mathrm{HCl}+10 \mathrm{ml}$ deionized water and boiled for few minutes. The $\mathrm{pH}$ of the solution was maintained at $\mathrm{pH} 3$ for adding the concentrated acid adding methyl orange indicator, the color changes to pink. Then, the solution is titrated against $0.1 \mathrm{M} \mathrm{NaOH}$ until the change of color occurs from pink to orange. The $\% \mathrm{DD}$ was calculated using the formula:

$$
\mathrm{NH}_{2} \%=\frac{(0.0-0.12) 0.016}{\mathrm{G}(100-\mathrm{W})} \times 100
$$

\section{Extraction of red algae}

Ten grams of algal powder were incubated $24 \mathrm{~h}$ with acetone to remove lipid and pigments. The residue was then dissolved in $5 \mathrm{ml}$ of $0.25 \mathrm{M} \mathrm{NaCl}$, and the $\mathrm{pH}$ was determined periodically and adjusted to 8 by dissolving in $\mathrm{NaOH}$. Trypsin $10 \mathrm{mg}$ was added to the content for proteolysis and incubated for $24 \mathrm{~h}$. After incubation, the content was filtered through cheesecloth; the filtrate was precipitated using ice-cold acetone under gentle agitation at $4^{\circ} \mathrm{C}$. The precipitate formed was centrifuged at $10,000 \mathrm{rpm}$ for $20 \mathrm{~min}$ and dried under vacuum. Formulation of red algae loaded aminoethyl chitosan nanoparticles [11].

\section{Preparation of aminoethyl chitosan nanoparticles}

Aminoethyl chitosan (0.17-0.18\% w/v) added to distilled water; it contains $2 \%$ acetic acid and $1.2 \%$ tween 80 . The solution was placed on a magnetic stirrer continuously for 68-72 h with an intermittent sonication every $24 \mathrm{~h}$ in a bath sonicator. Sodium sulfate $17 \%(\mathrm{w} / \mathrm{v}$ ) was added and stirred for $1 \mathrm{~h}$ on magnetic stirrer and sonicated again for $15 \mathrm{~min}$. The nanosized particles were precipitated out. The size was analyzed to be $395 \mathrm{~nm}$.

\section{Loading of nanoparticles with algae extract}

One hundred milliliters of the nanoparticles solution were centrifuged at $5000 \mathrm{rpm}$ for $15 \mathrm{~min}$. The wet pellet $(6 \mathrm{mg} / \mathrm{ml})$ was taken and suspended in normal saline containing $0.5 \mathrm{mg} / \mathrm{ml}$ of powdered extract of red algae. The suspension was stirred on a magnetic stirrer at 300-400 rpm for $4 \mathrm{~h}$ and later centrifuged to get loaded nanoparticles.

Determination of anti-HIV activity of the prepared nanoparticle $[12,13]$

The anti-HIV-1 reverse transcriptase (RT) activity of the compounds was carried out for assay using a non-radioactive colorimetric enzymelinked immunosorbent assay (ELISA) RT Assay Kit (Roche) [16]. The assay procedure followed as per Rawal et al. [17]. In brief, the detection and quantification of synthesized DNA were used as a parameter for RT activity that incorporates digoxigenin and biotin-labeled dUTP in DNA strand. The activity of compounds was measured at two different concentrations, 10 and $100 \mu \mathrm{g} / \mathrm{ml}$. The reaction mixture comprises $20 \mu \mathrm{l}$ each of dNTPs with template/primes complex, RT enzyme in the lysis buffer with the test compound to make a total volume of $60 \mu \mathrm{l}$, which was then incubated at $37^{\circ} \mathrm{C}$ for $1 \mathrm{~h}$. Nevirapine was used as a positive compound and $20 \mu \mathrm{l}$ lysis buffer with no RT was used as a negative control. The contents were then transferred to streptavidincoated microtiter plate wells and incubated at $37^{\circ} \mathrm{C}$ for $1 \mathrm{~h}$.

Post-incubation, plates were washed for 5 times each for 30 s with $250 \mu \mathrm{l}$ washing buffer to remove the unbound dNTPs followed by the addition of $200 \mu \mathrm{l}$ of anti-digoxigenin peroxidase (anti-DIG-POD, $200 \mathrm{mU} / \mathrm{ml}$ ) diluted in conjugate dilution buffer to each well. The plate was further incubated at $37^{\circ} \mathrm{C}$ for $1 \mathrm{~h}$ and the same washing process was repeated, followed by the addition of $200 \mu \mathrm{l}$ ABTS substrate solution/well, and incubated again at room temperature until sufficient color was developed. Optical density was measured by ELISA reader at $405 \mathrm{~nm}$ (reference wavelength $490 \mathrm{~nm}$ ). The RT activity of each compound is directly proportional to its resultant color intensity $[14,15]$.

\section{Anti-HIV-1 activity in TZM-bl cells $[16,17]$}

TZM-bl cells $(5 \times 104 /$ wel $)$ cultured in Dulbecco's Modified Eagle's Medium (DMEM; Sigma--Aldrich Inc., St. Louis, MO, USA) supplemented with $10 \%$ fetal bovine serum (FBS; Biological Industries, Kibbutz Beit Haemek, Israel) and an antibiotic-antimycotic cocktail (penicillin [100 units/ml], streptomycin $[100 \mu \mathrm{g} / \mathrm{ml}]$, and amphotericin B [250 ng/ml]; Biological Industries) was seeded in 24-well plate and incubated overnight at $37^{\circ} \mathrm{C}$ in humidified atmosphere of $5 \% \mathrm{CO}_{2}$. HIV-1 NL4.3 at a concentration equivalent to 0.05 multiplicity of infection with respect to seeded TZM-bl cells was treated with varying concentrations of compounds for $1 \mathrm{~h}$ at $37^{\circ} \mathrm{C}$ in separate vials. Subsequently, pretreated viruses were added in duplicate to TZM-bl cells growing in 24-well plate and incubated for $4 \mathrm{~h}$ at $37^{\circ} \mathrm{C}$ in humidified atmosphere of $5 \% \mathrm{CO}_{2}$. After incubation, medium was removed and cells washed once with cold $50 \mathrm{mM}$ PBS. Fresh culture medium supplemented with test compounds was added and cells further incubated for $48 \mathrm{~h}$ at $37^{\circ} \mathrm{C}$. Nevirapine was used as positive reference control, whereas appropriate volume of dimethyl sulfoxide used as negative control. $1 \times$ Promega cell culture lysis buffer (Promega Corporation, Madison USA) by freeze-thaw.

The supernatant was analyzed for the luciferase activity by Bright-Glo Luciferase Assay Kit (Promega Corporation, USA) in white Optiplate and luminescence was read using Fluorimeter (BMG Labtech $\mathrm{GmbH}$, Offenburg, Germany) at a spectral range of 240-740 nm. Anti-HIV-1 activity was calculated by taking the mean read out in experimental group divided by the mean read out in infected cells in the absence of test compound multiplied by 100 . The results were expressed as percentage inhibition by subtracting the above value from 100. Preformulation study of chitosan powder.

In vitro anti-HIV activity of the nanoparticle

The HIV-1 RT activity of the prepared nanoparticle is shown in Table 2. These compounds revealed the effect for the anti-HIV-1 activity.

\section{RESULTS AND DISCUSSION}

The results revealed the anti-HIV activity of the prepared nanoparticulate system. Cytotoxicity assay of the nanoparticulate system was carried out and the cytotoxic concentration 50\% (CC50) value was found to be $38.07 \pm 1.42 \mu \mathrm{g} / \mathrm{ml}$, indicating that the nanoparticulate system is not cytotoxic. HIV-1 infectivity inhibition assay was carried out and the nanoparticulate system showed good inhibitory activity with a half-maximal inhibitory concentration $\left(\mathrm{IC}_{50}\right.$ ) value of $3.75 \pm 0.57 \mu \mathrm{g} / \mathrm{ml}$. From the CC50 and IC $\mathrm{I}_{50}$ values, the selectivity index of the nanoparticle was found to be 17.65 compared to the standard drug nevirapine (82.32), indicating the usefulness of the formulated nanoparticulate system as potential anti-HIV agent. 
Table 1:

\begin{tabular}{ll}
\hline Variability under study & Appropriate value \\
\hline Moisture content & $1.8 \%$ \\
Ash content & $4.2 \%$ \\
Viscosity & $231 \mathrm{cps}$ \\
Viscosity-average & $332 \mathrm{kDa}$ \\
molecular weight & \\
Solubility & Soluble in $1 \%$ acetic acid solution and \\
& partially soluble in water \\
Degree of deacetylation & $80 \%$ \\
\hline
\end{tabular}

Table 2:

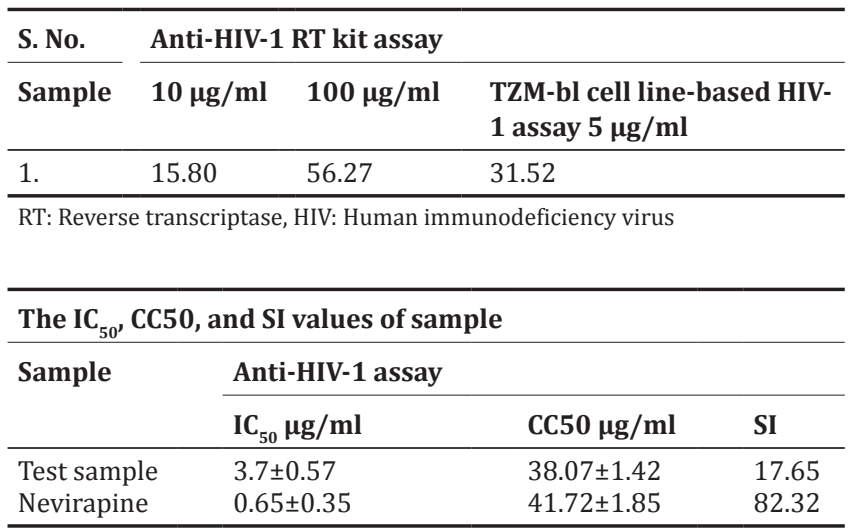

SI: Selectivity index, HIV: Human immunodeficiency virus, IC $_{50}$ : Half maximal inhibitory concentration, CC50: Cytotoxic concentration 50\%

\section{CONCLUSIONS}

\section{CONFLICTS OF INTERSET}

None.

\section{AUTHORS' CONTRIBUTIONS}

All authors have equally contributed for making this project to be successful.

\section{REFERENCES}

1. Vo TS, Kim SK. Potential anti-HIV agents from marine resources: An overview. Mar Drugs 2010;8:2871-92.
2. Mamo T, Moseman EA, Kolishetti N, Salvador-Morales C, Shi J, Kuritzkes DR, et al. Emerging nanotechology approaches for HIV/ AIDS treatment and prevention. Nanomedicine (Lond) 2010;5:269-85.

3. AIDS. The HIV Life Cycle; 2015.

4. National Institute of Allergy and Infectious Diseases. National Institute of Allergey and Infectious Diseases "How HIV Causes AIDS". Maryland: National Institute of Allergy and Infectious Diseases; 2009.

5. Arbia W, Arbia L, Adour L, Amrane A. Chitin extraction from crustacean shells using biological methods-a review. Food Tech Biotechnol 2013;51:12-25.

6. Cheung RC, Ng TB, Wong JH, Chan WY. Chitosan: An update on potential biomedical and pharmaceutical applications. Mar Drugs 2015;13:5156-86.

7. Chandy T, Sharma CP. Chitosan-as a biomaterial. Biomater Artif Cells Artif Organs 1990;18:1-24. Venkatesan J, Kim SK. Chitosan composites for bone tissue engineering-An overview. Mar Drugs 2010;8:2252-66

8. Kumar MN, Muzzarelli RA, Muzzarelli C, Sashiwa H, Domb AJ. Chitosan chemistry and pharmaceutical perspectives. Chem Rev 2004; 104:6017-84.

9. Islam MM, Masum SM, Rahman MM, Molla MA, Shaikh AA, Roy SK. Preparation chitosan from shrimp shells and investigation of its properties. Int J Basic Appl Sci 2011;11:116-30.

10. Li Q, Dunn T, Grandmaison EW, Goosen MF. Applications and properties of chitosan. J Bioact Compat Polym 1992;7:370-97.

11. Knaul JZ, Hudson SM, Creber KA. Properties of chitin and chitosan polymers. J Polym Sci 1999;72:1079-94.

12. He G, Wang Z, Zheng H, Yin Y, Xiong X, Lin R. Preparation, characterization and properties of aminoethyl chitin hydrogels. Carbohydr Polym 2012;90:1614-9.

13. Silva TM, Alves LG, Queiroz KC, Rocha HA, Leite EL. Partial characterization and anticoagulant activity of a heterofucan from the brown seaweed Padina gymnospora. Braz J Med Biol Res 2005;38:523-33.

14. Nirmala MJ, Shiny PJ, Ernest V, Dhas SP, Samundeeswari A, Mukherjee A, et al. A review on safer means of nanoparticle synthesis by exploring the profilic marine ecosystem as a new thrust area in nanopharmaceutics. Int J Pharm Pharm Sci 2012;5:23-39.

15. Tiruwa R. A review on nanoparticles-preparation and evaluation parameters. Indian J Pharm Biol Res 2016;9:555.

16. Murugesan V, Prabhakar YS, Katti SB. CoMFA and CoMSIA studies on thiazolidine-4-one as anti-HIV-1 agents. J Mol Graph Model 2009;27:735-43

17. Rawal RK, Tripathi R, Kulkarni S, Paranjape R, Katti SB, Pannecoque C, et al. 2-(2,6-Dihalo-phenyl)-3-heteroaryl-2-ylmethyl-1, 3-thiazolidine4ones: Anti-HIV agents. Chem Biol Drug Des 2008;72:147-54.

18. Rengasamy $\mathrm{S}$, Thangaprakasam $\mathrm{U}$, et al. Isolation, screening and determination of $\alpha$-amylase activity from marine Streptomyces species. Int J Pharm Pharm Sci 2017;10:122-7. 